\title{
Artrose kan behandles på flere måter
}

\author{
Artrosebehandling er ikke bare operasjon. Trening for å bevare bevegelsesutslag samt opprettholde \\ og styrke muskulatur og leddsans er viktig og må ikke glemmes. Tilstanden er kronisk, behandlingen \\ bør derfor være så enkel at pasienten kan gjøre den jevnlig på egen hånd.
}

For ti år siden fikk jeg besøk av en pasient med store plager fra artrose i det ene kneet. Han hadde tatt røntgenbilde av kneet og fått vurdering av ortoped, som konkluderte med at det var så stor artrose at protese var eneste aktuelle behandling. Pasienten var fysisk svært aktiv, både på ski og med fotturer i fjellet, og var lite innstilt på proteseoperasjon. Han kjente til at jeg hadde lang erfaring med behandling av idrettsutøvere med plager fra muskler og ledd, og ba om time, selv om han ikke var en av mine ordinære pasienter.

Jeg har i mange år vært opptatt av at $\mathrm{i}$ behandling av leddplager må man legge til rette for å bevare bevegelsesutslaget $\mathrm{i}$ leddet, opprettholde og styrke muskulaturen rundt leddet og sørge for at leddsansen er best mulig. Med en kronisk plage som artrose må behandlingen være så enkel at det er noe pasienten kan gjøre på egen hånd daglig eller flere dager i uken.

Mannen fikk råd om å trene styrken i musculus vastus medialis ved à fylle en bøtte med stein og løfte den ti ganger med hvert bein med bøtten hengende på vristen.

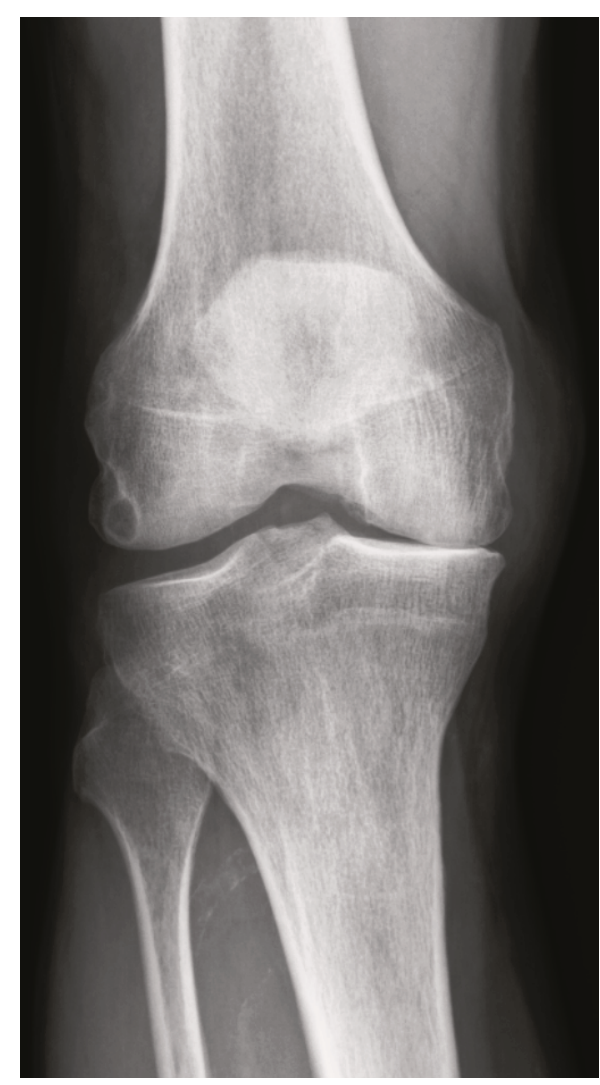

Artrotisk kne. Foto Volda sjukehus
Bøtten skulle være så tung at han ikke ville klare å løfte den 20 ganger. M. vastus medialis strekker kneet de siste 15-20 gradene og er en viktig muskel for stabilisering av leddet. Min erfaring er at det er tilstrekkelig å trene kun i denne sektoren, noe som også gir liten belastning på brusken i leddet. I tillegg rådet jeg ham til å sykle 20-30 minutter to-tre ganger i uken, enten på vanlig sykkel eller på ergometersykkel når været var lite egnet for utesykling. Han fikk også råd om tøyningsøvelser for å opprettholde bevegeligheten i kneet og om å gå tur i utmark så ofte som mulig for å bedre leddsansen.

I høst møtte jeg vedkommende igjen ved en tilfeldighet. Han er blitt 78 år og er fortsatt svært sprek. Dagen etter skulle han delta i turløpet Skåla opp - en svært bratt fjelltur til toppen av den 1848 meter høye Skåla i Loen. Jeg spurte da om han ikke hadde kneplager som gjorde det vanskelig. Nei, kneplager hadde han ikke, men han trente regelmessig, som han hadde fått råd om ti år tidligere. En uke senere snakket jeg med ham igjen og spurte om han hadde vært på Skåla. Han svarte ja. Dagen etter Skåla-turen hadde han deltatt i et $50 \mathrm{~km}$ langt lokalt sykkelløp.

En «vanlig sykehistorie» med artrose i hofte og kne i Norge er klinisk undersøkelse, røntgenundersøkelse, smertestillende og henvisning til $12-15$ behandlinger hos fysioterapeut. Dersom det fortsatt er mye plager, henvises pasienten til vurdering for proteseoperasjon.

\section{Regelmessig trening}

Ut fra kasuistikken over og min erfaring fra et langt liv som fastlege, med spesiell interesse for ledd og muskelplager, hevder jeg at plager på grunn av artrose bør behandles på en annen måte. Selv med store smerter fra et artrotisk ledd vil normalisering av bevegeligheten, god kraft i støttemuskulaturen rundt leddet og god leddsans ofte føre til normal funksjon og smertefrihet i leddet. Men behandlingen må legges opp på en måte som gjør at pasienten selv kan fortsette å trene regelmessig. Når jeg har gitt råd, har jeg vist til at trening for artrose er som å pusse tenner. Det er ikke noe man gjør 10-15 ganger og så er «behandlingen» over.

En liknende behandling som det jeg har rådet til, er blitt vanlig i Sverige - $\mathrm{i}$ form av «kneskole» og «hofteskole» (1). Behandlingen strekker seg over 6-12 måneder og veksler mellom teori og veiledet trening hos fysioterapeut samt regelmessig egentrening. Et slikt behandlingsopplegg er sett på som ønskelig før henvisning til ortoped for vurdering for proteseoperasjon. For kneleddsartrose viser resultatene fra kneskolen i Umeå at vel halvparten er fornøyd med resultatet $1-3$ år senere, og at bare $13 \%$ er operert med protese i denne perioden (2).

Pasienten har gitt samtykke til at artikkelen blir publisert.

\section{Torbjørn Måseide}

torbjornm@mimer.no

Torbjørn Måseide (f. 1940) er pensjonert kommuneoverlege og fastlege i Ulstein.

Forfatter har fylt ut ICMJE-skjemaet og oppgir ingen interessekonflikter.

\section{Litteratur}

1. Bättre Omhändertagande av patienter med Artros (BOA). www.boaregistret.se $(9.4 .2013)$.

2. Boaregisterets årsrapport 2011, s. 94-5. www.boaregistret.se/Libraries/ doc3_-_\%c3\%85rsrapporter/ BOA_arsrapport_2011.sflb.ashx (9.4.2013).

Mottatt 25.1. 2013, første revisjon innsendt 9.4. 2013, godkjent 16.4. 2013. Medisinsk redaktør Are Brean.

Publisert først på nett 